\title{
Gene expression profiles in Finnish twins with multiple sclerosis Silja Särkijärvi ${ }^{1}$, Hanna Kuusisto ${ }^{2}$, Raija Paalavuo ${ }^{1}$, Mari Levula ${ }^{3}$, Nina Airla ${ }^{3}$, Terho Lehtimäki ${ }^{3}$, Jaakko Kaprio ${ }^{4,5}$, Markku Koskenvuo ${ }^{4}$ and Irina Elovaara*1,2
}

\begin{abstract}
Address: ${ }^{1}$ Neuroimmunology Unit, Department of Neurology, Tampere University Hospital, Teiskontie, 35, 33520 Tampere, Finland, ${ }^{2}$ Department of Neurology, Tampere University Hospital, Teiskontie 35, 33520 Tampere, Finland, ${ }^{3}$ Laboratory of Atherosclerosis Genetics, Department of Clinical Chemistry, Center for Laboratory Medicine, Tampere University Hospital, and Medical School, University of Tampere, Teiskontie 35, 33520 Tampere, Finland, ${ }^{4}$ Department of Public Health, P.O. Box 41, University of Helsinki, FIN-00014 Helsinki, Finland and ${ }^{5}$ Department of Mental Health and Alcohol Research, National Public Health Institute, Mannerheimintie 166, FIN-00300 Helsinki, Finland

Email: Silja Särkijärvi - silja.sarkijarvi@uta.fi; Hanna Kuusisto - hanna.kuusisto@pshp.fi; Raija Paalavuo - raija.paalavuo@uta.fi; Mari Levula - mari.levula@uta.fi; Nina Airla -nina.airla@uta.fi; Terho Lehtimäki - terho.lehtimaki@uta.fi; Jaakko Kaprio - jaakko.kaprio@helsinki.fi; Markku Koskenvuo - markku.koskenvuo@pp.inet.fi; Irina Elovaara* - irina.elovaara@uta.fi

* Corresponding author
\end{abstract}

Published: 27 February 2006

BMC Medical Genetics2006, 7:1 I doi:10.1 I86/147|-2350-7-I I
Received: 08 April 2005

Accepted: 27 February 2006

This article is available from: http://www.biomedcentral.com/I47I-2350/7/I I

(C) 2006Särkijärvi et al; licensee BioMed Central Ltd.

This is an Open Access article distributed under the terms of the Creative Commons Attribution License (http://creativecommons.org/licenses/by/2.0), which permits unrestricted use, distribution, and reproduction in any medium, provided the original work is properly cited.

\begin{abstract}
Background: Since genetic alterations influencing susceptibility to multiple sclerosis (MS), the most common autoimmune demyelinating disease of the central nervous system (CNS), are as yet poorly understood, the purpose of this study was to identify genes responsible for MS by studying monozygotic (MZ) twin pairs discordant for MS.

Methods: In order to identify genes involved in MS development, the gene expression profiles in blood mononuclear cells obtained from eight MZ twin pairs discordant for MS were analyzed by cDNA microarray technology detecting the expression of 8300 genes. The twins were collected from the Finnish Twin Cohort Study and both affected subjects and their healthy siblings underwent neurological evaluation and cerebral and spinal magnetic resonance imaging. Gene expressions were confirmed by relative quantitative reverse transcription PCR.

Results: It appeared that 25 genes were at least two-fold up-regulated and 15 genes downregulated in $25 \%$ (2/8) of twins with MS when compared to their healthy siblings. Moreover, 6/25 genes were up-regulated in $40 \%$ of MS twins and one gene, interferon alpha-inducible protein (clone IFI-6-I6) (GIP3), in $50 \%$ of them. The six most constantly expressed genes are (I) GIP3, (2) POU domain, class 3, transcription factor I, (3) myxovirus resistance 2, (4) lysosomal-associated multispanning membrane protein-5, (5) hemoglobin alpha 2 and (6) hemoglobin beta.

Conclusion: Over two-fold up-regulation of these six genes in almost half of MZ twins with MS suggests their role in MS pathogenesis. Studies using MZ MS twins obtained from genetically homogeneous population offer a unique opportunity to explore the genetic nature of MS.
\end{abstract}

\section{Background}

Multiple sclerosis (MS) is the most common autoimmune demyelinating disease of the central nervous system (CNS) characterised by inflammatory lesions scattered 
throughout the brain tissue. According to recent data the prevalence of MS in Finland is the highest in the world being 100/100 000, although the figures vary in different regions of the country [1]. The reasons for the increase in the disease prevalence are not known, although viral infections and other environmental factors have been suggested [1].

Family and twin studies have shown that the concordance rate of MS for monozygotic (MZ) twins is about $30 \%$ and $2-5 \%$ for dizygotic (DZ) twins and siblings [2-4]. In a Finnish twin cohort of 15815 pairs, the concordance rate of MS was $29 \%$ in MZ twins and the concordance rate was $0 \%$ in DZ twins [5].

It is well known that genetic factors regulate susceptibility to MS, but of these factors only HLA-DR2 has been confirmed to be associated with the disorder [6]. In our previous studies several susceptibility genes and their associations have been reported [7-15]. These are the protective effect of HLA-DR1 and HLA-DR53 combination against MS [9], decreased risk of severe MS of IL-10-1082 AG genotype carriers [12] and high chemokine receptor 5 (CCR5) RNA expression in peripheral blood in primary progressive MS [8]. Increased risk of MS in women has been detected with interleukin-1 receptor antagonist (IL1RA) allele 2 [11], 5G5G genotype of plasminogen activator inhibitor 1 (PAI-1) gene [10] and interaction between estrogen receptor 1 (ESR1) and HLA-DR2 [13]. Other associations with MS in Finnish population are myelin basic protein (MBP) short tandem repeat [15], intercellular adhesion molecule-1 (ICAM-1) AA genotype (Lys ${ }^{469} /$ Lys $^{469}$ ) [14] and preliminary evidence of two distinct MS susceptibility genes, proximal rs3977 and distal D2S1271-associated genes, on 2q33 outside of cytotoxic T-lymphocyte-associated 4 (CTLA4) gene [7]. Taken together, these observations suggest that experimental approach using MZ twin pairs discordant for MS obtained from Finnish genetically relatively homogeneous population may provide a unique opportunity to explore the genetic nature of MS. Interestingly, one study performed on monozygotic twins with MS reported deficient expression of the inhibitory transcription factor $\mathrm{Sp} 3$ in mononuclear blood cells [16].

Since genetic factors influencing MS susceptibility and progression are as yet poorly understood, the purpose of this study was to identify genes responsible for MS development by studying $\mathrm{MZ}$ twin pairs discordant for MS identified from the Finnish Twin Cohort Study and using cDNA array technology involving the expression profiles of 8300 known genes.

\section{Methods \\ Study subjects}

We studied eight $M Z$ twin pairs discordant for MS obtained from the Finnish Twin Cohort Study. Patients of MS were identified by linkage to the national hospital discharge registry, which covers all hospitalization in Finland since 1972. All the twin pairs, both affected subjects and their healthy twin siblings, underwent neurological evaluation and magnetic resonance imaging (MRI) of the CNS using 1,5 Tesla MRI unit during a clinical remission of the disease. From the MRI protocol, axial 3 dimensional (3D) T2 fast spin echo (FSE), T1 3D axial spoiled gradient echo (SPGR) and FLAIR sequences were used. T2 hyperintense plaques were analyzed from 3D T2 FSE images, T1 hypointense plaques from 3D T1 SPGR images and FLAIR lesions from FLAIR images. All MS patients showed T1and T2-lesions characteristic to MS, but Gadoliniumenhanced focal lesions were not detected. The diagnosis of MS was based on Poser's criteria and all diagnoses were definite [17]. The affected twins had no other diseases and their twin siblings were all healthy. The mean age of twin pairs was $51.1 \pm 9.1(\mathrm{SD})$ years. The neurological disability evaluated by the Expanded Disability Status Scale (EDSS) score was $5.1 \pm 1.9$ (mean \pm SD). The clinical characteristics of twin pairs are shown in Table 1. Four out of 8 twins with MS were treated with interferon beta (IFN- $\beta$ ). One of them had received this treatment for 1 year (patient No2, table 1) and the remaining three patients for two to three years. (patients No3, 5 and 6). In addition most of MS patients had symptomatic medication. The peripheral blood samples were collected during a clinical remission of the disease and the analyses were performed blind to disease status.

\section{Isolation of total RNA}

Mononuclear cells were separated from peripheral blood (PBMC) in VACUTAINER ${ }^{\oplus}$ CPT $^{\text {TM }}$ Cell Preparation Tubes (Becton Dickinson and Company, Franklin Lakes, N.J., USA) and total RNA were isolated by RNeasy ${ }^{\oplus}$ Mini Kit (QIAGEN, Valencia, CA, USA) according to the manufacturer's protocols. The DNA was removed according to BD Atlas $^{\mathrm{TM}}$ Plastic Microarrays (BD Biosciences Clontech, Palo Alto, CA, USA) user manual for DNase treatment of total RNA for $10 \mu \mathrm{g}$ of RNA, with the exception that RNA precipitation was carried out overnight at $-20^{\circ} \mathrm{C}$. The quality of total RNA was checked by gel electrophoresis and stored at $-70^{\circ} \mathrm{C}$ until used.

\section{cDNA microarrays}

The study was performed using BD Atlas ${ }^{\mathrm{TM}}$ Plastic Human 8 K Microarrays (BD Biosciences Clontech, Palo Alto, CA, USA), which contains duplicate DNA fragments from more than 8300 known human genes (a list of genes is available at http://www.clontech.com/clontech/atlas/ genelists/). $5 \mu \mathrm{g}$ of total RNA were used for microarray 
Table I: Clinical characteristics of monozygotic twin pairs.

\begin{tabular}{|c|c|c|c|c|c|c|}
\hline Twin pair no & Gender & Age & Duration of MS (years) & Type of MS & EDSS & Immunomodulatory treatment \\
\hline \multirow[t]{2}{*}{1} & $\mathrm{~F}$ & 54 & 11 & SP & 1.5 & n.t. \\
\hline & $\mathrm{F}$ & 54 & Healthy/0 & Healthy & & \\
\hline \multirow[t]{2}{*}{2} & $\mathrm{~F}$ & 48 & 1 & $\mathrm{RR}$ & 4.0 & IFN- $\beta$-Ia \\
\hline & $\mathrm{F}$ & 48 & Healthy/0 & Healthy & & \\
\hline \multirow[t]{2}{*}{3} & $\mathrm{~F}$ & 55 & 9 & SP & 7.0 & IFN- $\beta-I b$ \\
\hline & $\mathrm{F}$ & 55 & Healthy/0 & Healthy & & \\
\hline \multirow[t]{2}{*}{4} & M & 53 & 23 & SP & 6.5 & n.t. \\
\hline & $M$ & 53 & Healthy/0 & Healthy & & \\
\hline \multirow[t]{2}{*}{5} & $\mathrm{~F}$ & 33 & 5 & RR & 4.0 & IFN- $\beta-I \mathrm{a}$ \\
\hline & $\mathrm{F}$ & 33 & Healthy/0 & Healthy & & \\
\hline \multirow[t]{2}{*}{6} & $\mathrm{~F}$ & 54 & 3 & $\mathrm{RR}$ & 4.5 & IFN- $\beta-I b$ \\
\hline & $F$ & 54 & Healthy/0 & Healthy & & \\
\hline \multirow[t]{2}{*}{7} & $M$ & 66 & 11 & SP & 6.5 & n.t. \\
\hline & $M$ & 66 & Healthy/0 & Healthy & & \\
\hline \multirow[t]{2}{*}{8} & $M$ & 46 & 22 & $S P$ & 6.5 & n.t. \\
\hline & $M$ & 46 & Healthy/0 & Healthy & & \\
\hline
\end{tabular}

F female; M male; n.t. no treatment; EDSS Expanded Disability Status Scale; IFN- $\beta$ beta-interferon

analyses and samples from MZ twin pairs were analyzed at the same time. Microarrays were exposed to phosphoimaging screen and scanned by StormScan 840 Phosphoimager (Molecular Dynamics, Sunnyvale, CA, USA) after 5-7 days exposure time at a resolution of $50 \mu \mathrm{m}$ to ImageQuant software version 5.1 (Molecular Dynamics, Sunnyvale, CA, USA). The comparison was done for all 8 discordant monozygotic twin pairs and all 8300 genes by using widely used cDNA subtraction procedure according to manufacturer's instructions (Clontech, Palo Alto, CA, USA). In brief, in our array, RNA sample obtained from healthy $\mathrm{MZ}$ twin (tissue No1) was compared to corresponding RNA obtained from $\mathrm{MZ}$ twin with MS (tissue No2) by using cDNA subtraction method.

\section{Data analysis and normalization}

Analysis was performed using the BD AtlasImage ${ }^{\mathrm{TM}} 2.7$ Beta software (BD Biosciences Clontech, Palo Alto, CA, USA) and data was globally normalized by the sum method. Normalized signal intensities were compared to those of healthy siblings. Ratios of gene expression greater than two-fold were considered significant, based on a $99 \%$ confidence interval $[18,19]$. The data was further analyzed and visualized with the GeneSpring software version 5.0 (Silicon Genetics, San Carlos, CA, USA) and the detailed principles of the cluster analysis and dendrograms can be found from the GeneSpring GX animated tutorial from the internet http://www.chem.agilent.com/ scripts/pds.asp?lpage=27881.

\section{Quantitative reverse transcription polymerase chain reaction (QRT-PCR)}

The cDNA microarray data was confirmed for interferon alpha-inducible protein gene (clone IFI-6-16) (G1P3) by relative quantitative real-time RT-PCR with LightCycler instrument (Roche Diagnostics GmbH, Mannheim, Germany). $1 \mu \mathrm{g}$ of total RNA was converted into cDNA with Random Primer $\mathrm{p}(\mathrm{dN})_{6}$ using 1st Strand cDNA Synthesis Kit for RT-PCR (AMV) (Roche Diagnostics Corporation, Indianapolis, IN, USA). The primers and hybridization probes for QRT-PCR were designed and prepared by TIB MolBiol (Berlin, Germany) and the sequences are the following: forward primer: 5'-GAGTGCAGTGGCTATTCACA-3', reverse primer: 5'GCGCATGCTTGTAATCCTAC-3', probe 5'-end labeled with acceptor dye LC Red 640: 5'-AGCCTCAAGTGATCCTCCTGTCTCA-3' and probe 3'-end labeled with fluorecein: 5'-CATAGTACACTGCAGCCTCCAACTCC-3'.

The PCR was performed in a $20 \mu \mathrm{l}$ total volume for target gene with $2 \mu$ l LightCycler FastStart DNA Master Hybridization Probes (Roche Diagnostics GmbH), $3 \mathrm{mM} \mathrm{MgCl}_{2}$, $0.2 \mu \mathrm{M}$ each probe, $0.5 \mu \mathrm{M}$ each primer and $2 \mu \mathrm{l}$ of cDNA. The PCR was performed with a denaturation at $95^{\circ} \mathrm{C}$ for $10 \mathrm{~min}$, amplified in 40 cycles of denaturation at $95^{\circ} \mathrm{C}$ for $10 \mathrm{~s}$, annealing at $60^{\circ} \mathrm{C}$ for $15 \mathrm{~s}$ and elongation at $72^{\circ} \mathrm{C}$ for $12 \mathrm{~s}$. The cooling was performed at $40^{\circ} \mathrm{C}$ for $30 \mathrm{~s}$.

Glucose-6-phosphate dehydrogenase (G6PDH) was used as a reference gene. The PCR for this was performed by LightCycler - h - G6PDH Housekeeping Gene Set Kit (Roche Diagnostics $\mathrm{GmbH}$ ) and was done at the same time and under the same PCR conditions as for the target gene. All reactions for target and reference gene were performed in duplicates. Agarose gel electrophoresis was used to verify the PCR products. QRT-PCR results were calculated by LightCycler Relative Quantification Software with efficiency correction (Roche Diagnostics $\mathrm{GmbH})$. 


\section{Statistical analyses}

The significantly expressed genes in our array experiments were defined according to the instructions given by the cDNA array manufacturer (Clontech, Palo Alto, CA, USA). cDNA subtraction ratios of gene expression greater than two-fold were considered significant, based on a $99 \%$ confidence interval. The differences of at least 2-fold upor down-regulated genes within MS twin groups were compared with McNemar test and $\chi-2$ test using statistical software STATA version 8.0 (STATA Corporation, TX, USA) A p-value of less than 0.05 was considered significant.

\section{Results}

\section{Gene expressions in $M Z$ twin pairs discordant for MS}

The numbers of significantly up- or down-regulated genes (at least two-fold difference in expression between twin pairs) in the PBMC of MZ pairs discordant for MS detected by cDNA microarray are shown in Table 2. Comparison between twin pairs showed that 305/8 300 genes were at least two-fold up- or down-regulated in at least $1 / 8$ twins with MS. The proportion of up-regulated genes was significantly higher compared to the proportion of down-regulated genes ( $\mathrm{p}=0.023$ for the difference, $\chi$ - 2 test $)$. Moreover, 38/305 genes were up- or down-regulated in at least one fourth (2/8) of MS twin pairs (Table 2 and 3). Of these 38 genes, 15 were down-regulated ( 2 to 10 fold) and 25 up-regulated ( 2 to 39 fold). 6/25 up-regulated genes were expressed in at least $40 \%(3 / 8)$ of MS twin pairs (Table 2), while none of the 15 down-regulated genes were detected with this high frequency ( $\mathrm{p}=0.01$ for the difference of up- and down-regulated genes in $\chi-2$ test). One gene, interferon alpha-inducible protein (clone IFI-616) (G1P3), appeared to be up-regulated in 50\% (4/8) of the MZ MS twin pairs.

The hierarchical relationship among ratios of gene expression of 23 most significantly expressed genes between healthy sibling and otherwise identical sibling with MS were compared with cluster analysis. These results are displayed as a dendrogram in Figure 1. As shown by the figure the twin pair samples are roughly divided into two main branches, left branch including twin pairs $1-5$ and right branch including twin pairs $6-7$. In order to find clinical differences between the branches we characterized these two groups according to the clinical criteria shown in Table 1. From the left branch pairs 1-5 three had SP type $(3 / 5,60 \%)$ and two RR type of MS and from the right branch two of the twins had SP $(2 / 3,67 \%)$ and one RR type of MS (Table 1 ). Thus these 23 genes were insufficient to separate between relapsing-remitting and secondary progressive MS. From the left branch pairs three (3/5, $60 \%$ ) of the diseased siblings got IFN- $\beta-1 \mathrm{~b}$ treatment and from the right branch pair one of the three siblings $(1 / 3$, $33 \%$ ) received this treatment. Also the average EDSS,
Table 2: Number of up- or down-regulated genes in the discordant twins with MS compared to their healthy siblings.

\begin{tabular}{llll}
\hline & \multicolumn{3}{c}{ Number of twin pairs } \\
\cline { 2 - 4 } & $1 / 8^{*}$ & $2 / 8^{* *}$ & $3 / 8$ \\
\hline Up-regulated & 194 & 25 & 6 \\
Down-regulated & 111 & 15 & 0 \\
Total no of genes with change & 305 & 38 & 6 \\
\hline
\end{tabular}

Genes with at least two-fold change are included.

The proportion of up-regulated genes was significantly higher compared to the proportion of down-regulated genes within twin pair groups $*_{p}=0.023 ;{ }^{* *} p=0.01$ in $\mathrm{X}-2$ test.

duration of the MS and mean age of the sibling pairs tended to be lower in the left branch subjects (mean EDSS $=4.6$, and mean duration 9.8 years, mean age 48.6 years, respectively) than in the three subjects involved in the right branch (mean EDSS 5.8, mean duration 12.0 years, and mean age 55.3 years, respectively). Furthermore, four of the total five siblings $(4 / 5,80 \%)$ in the left branch were women and in the right branch two of the total tree pairs were men $(2 / 3,67 \%)$.

The six most constantly expressed genes are shown in the Table 4. They are the following: (1) G1P3, (2) POU domain, class 3, transcription factor 1 (POU3F1), (3) myxovirus resistance 2 (MX2), (4) lysosomal-associated multispanning membrane protein-5 (LAPTM5), (5) hemoglobin alpha 2 (HBA2) and (6) hemoglobin beta (HBB). Over two-fold up-regulation of these six genes in $40 \%$ of MZ MS twins suggests their role in MS pathogenesis. However, no marked associations between gene expressions and neurological or MRI findings were detected. The expression level of G1P3 confirmed by QRTPCR appeared to be almost identical with the results obtained by cDNA microarray indicating that our method was working properly (Figure 2).

\section{Discussion}

The present study applying modern technique and experimental approach where gene expression profiles of $\mathrm{MZ}$ twin pairs discordant for MS were compared to each other revealed differential expression of 305 genes out of 8300 genes studied. Among the differentially expressed genes the proportion of up-regulated genes was significantly higher than that of down-regulated ones (64\% vs. $36 \%$ ). This observation may reflect the balance between immunoactivating and immunoinhibitory factors during the complex inflammatory cascade in MS.

It is noteworthy that up-regulated expression of six genes was found in half of twins with MS. This observation together with the fact that the MS twins were obtained from genetically homogeneous Finnish population sug- 
Table 3: The most constantly expressed genes $(n=38)$ having at least two-fold change, up- $(n=25)$ or down- $(n=15)$ regulation, simultaneously in $\mathbf{2}$ of $\mathbf{8}$ discordant identical twins with MS when compared to their healthy siblings.

\begin{tabular}{|c|c|c|c|}
\hline Gene group/symbol & GenBank accession no. & Description & $\begin{array}{l}U_{P}(\uparrow) \text { or down }(\downarrow) \\
- \text { regulation of genes }\end{array}$ \\
\hline \multicolumn{4}{|c|}{ Basic transcription factors } \\
\hline POU3FI & NM 002699 & POU domain, class 3 , transcription factor I & $\uparrow$ \\
\hline NKX2-5 & NM 004387 & Cardiac-specific homeobox & $\uparrow$ \\
\hline $\mathrm{PHOX} 2 \mathrm{~A}$ & NM 005169 & Aristaless (drosophila) homeobox & $\uparrow$ \\
\hline \multicolumn{4}{|l|}{ Cell surface antigens } \\
\hline$M \times 2$ & M30818 & Myxovirus (influenza) resistance 2 & $\uparrow$ \\
\hline LY6E & NM 002346 & Lymphocyte antigen 6 complex, locus $E$ & $\uparrow$ \\
\hline NKG7 & NM 005601 & Natural killer cell group 7 sequence & $\downarrow$ \\
\hline ITGAL & NM 002209 & Integrin, alpha L, lymphocyte function-associated antigen I (CDIIA) & $\downarrow$ \\
\hline CD4 & MI2807 & T cell surface glycoprotein CD4 antigen ( $\mathrm{p} 55)$ & $\downarrow$ \\
\hline \multicolumn{4}{|c|}{ Growth factors, cytokines and chemokines } \\
\hline PPBP & M54995 & Pro-platelet basic protein & $\downarrow$ \\
\hline SCGF & D86586 & Stem cell growth factor & $\downarrow$ \\
\hline \multicolumn{4}{|c|}{ Intracellular transducers/effectors/modulators } \\
\hline VBPI & NM 003372 & Von Hippel-Lindau binding protein I & $\uparrow$ \\
\hline STK3 & NM 006281 & Serine/threonine kinase 3 (STE20 homolog, yeast) & $\uparrow$ and $\downarrow$ \\
\hline \multicolumn{4}{|c|}{ 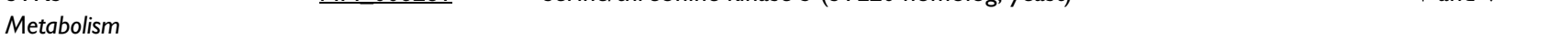 } \\
\hline HBAI & NM 000558 & Hemoglobin, alpha I & $\uparrow$ \\
\hline HBA2 & NM 000517 & Hemoglobin, alpha 2 & $\uparrow$ \\
\hline HBB & NM 000518 & Hemoglobin, beta & $\uparrow$ \\
\hline $\mathrm{ECHI}$ & NM 001398 & Enoyl Coentzyme A hydratase I, peroxisomal & $\uparrow$ \\
\hline ARSA & NM 000487 & Arylsulfatase A & $\uparrow$ \\
\hline HPRTI & V00530 & Hypoxanthine phosphoribosyltransferase I & $\downarrow$ \\
\hline GAPD & $\underline{x 01677}$ & Glyceraldehyde-3-phosphate dehydrogenase & $\downarrow$ \\
\hline \multicolumn{4}{|l|}{ Ribosomal proteins } \\
\hline RPS9 & $\underline{U} 14971$ & Ribosomal protein S9 & $\uparrow$ \\
\hline RPSI 2 & NM 001016 & Ribosomal protein $\mathrm{SI} 2$ & $\uparrow$ \\
\hline RPS20 & NM 001023 & Ribosomal protein $\mathrm{S} 20$ & $\uparrow$ \\
\hline RPS29 & NM 001032 & Ribosomal protein $\$ 29$ & $\uparrow$ \\
\hline RPL3 & NM 000967 & Ribosomal protein L3 & $\uparrow$ \\
\hline RPL9 & NM 000661 & Ribosomal protein L9 & $\uparrow$ \\
\hline RPL39 & NM 001000 & Ribosomal protein L39 & $\uparrow$ \\
\hline LAMRI & $\underline{\mathrm{U} 43901}$ & Laminin receptor I & $\uparrow$ and $\downarrow$ \\
\hline RPS5 & NM 001009 & Ribosomal protein S5 & $\downarrow$ \\
\hline RPL27A & NM 000990 & Ribosomal protein L27a & $\downarrow$ \\
\hline RPL30 & NM 000989 & Ribosomal protein L30 & $\downarrow$ \\
\hline RPL38 & NM 000999 & Ribosomal protein L38 & $\downarrow$ \\
\hline \multicolumn{4}{|l|}{ Others } \\
\hline GIP3 & $\times 02492$ & Interferon-induced protein (6-16, IFI6-16) & $\uparrow$ \\
\hline LAPTM5 & NM 006762 & Lysosomal-associated multispanning membrane protein- 5 & $\uparrow$ \\
\hline $\mathrm{AMH}$ & NM 000479 & Anti-Mullerian hormone & $\uparrow$ \\
\hline GPR6 & NM 005284 & G protein-coupled receptor 6 & $\uparrow$ \\
\hline BNIP3L & NM 004331 & BCL2/adenovirus EIB 19 kD-interacting protein 3-like & $\uparrow$ \\
\hline ACTB & $\times 00351$ & Actin, beta & $\downarrow$ \\
\hline
\end{tabular}

gests the importance of these genes in MS. To the best of our knowledge none of the six genes has previously been reported to be associated with MS. The sample was relatively small, but not unexpected given that MS is relatively rare, as is $\mathrm{MZ}$ twinning (about $0.4 \%$ of births are $\mathrm{MZ}$ twin births), The Finnish Twin Cohort covers virtually all twins alive in 1975 and born before 1958 [20], while the hospital discharge registry identified nearly all MS cases in Finland.
Expression of G1P3 was up-regulated in half of our MS twins. It is known that this gene is transcriptionally induced by IFN $-\alpha$ and $-\beta$ [21-23], virus infections [24-26] and tumour necrosis factor [27], but its function remains unknown. It is interesting that Ifi-6-16 peptide translated by G1P3 has been identified as an abundant self-peptide induced following measles virus (MV) infection [28], which has previously been associated with MS [29-31]. Since most of our MS twins were treated with IFN- $\beta$, the 


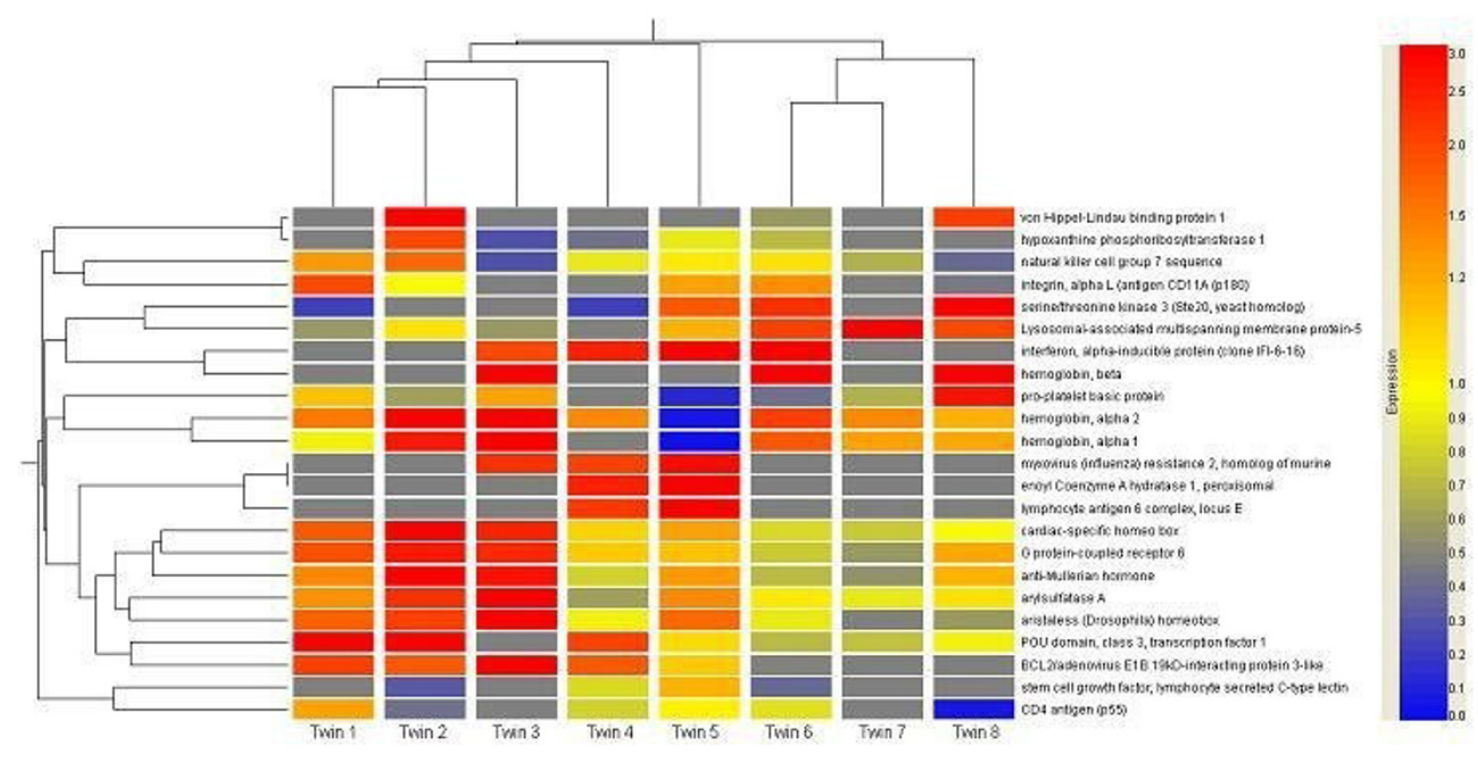

\section{Figure I}

Hierarchical clustering showing relative gene expressions comparing patients with MS to their healthy siblings. Genes with at least two-fold up- or down-regulation in $25 \%$ of MS twins are presented. Housekeeping genes and ribosomal protein genes are not included. The colorbar on the right shows the color representation of gene expressions. Grey color indicates the lack of expression in cDNA microarray and twin represents twin pair. The column dendrogram on the left shows the similarity between the expression of different genes and column dendrogram above the similarity in the gene expression profiles of twins. The data was visualized with the GeneSpring software version 5.0 (Silicon Genetics, San Carlos, CA, USA) and the detailed principles of the cluster analysis and dendrograms can be found from the GeneSpring GX animated tutorial from the internet http://www.chem.agilent.com/scripts/pds.asp?!page=2788I. See also text for the interpretation of the figure.

up-regulation of G1P3 in their PBMC can most likely be explained by the IFN- $\beta$ treatment or some unknown virus infection.

Twins with MS had up-regulated expression of POU3F1. The protein (SCIP/Oct-6) translated by this gene has mostly been studied in the nervous system, where it is associated with Schwann cells in the process of remyelination [32]. In oligodendrocytes, cells producing myelin in the CNS, the SCIP/Oct-6 can stimulate the expression of the papovaviral JC regulatory genes in progressive multifocal leukoencephalopathy (PML) [33], a demyelinating disease of the CNS. However, immune response to the JC virus has not so far been detected in MS.

Table 4: The six most constantly expressed genes detected by cDNA microarray.

\begin{tabular}{|c|c|c|c|c|}
\hline Gene symbol & GeneBank accession no. & Description & Function & $\begin{array}{l}\text { No of twin pairs with up- } \\
\text { regulated gene expression }\end{array}$ \\
\hline GIP3 & $\times 02492$ & Interferon-induced protein 6-16 & Unknown & 4 \\
\hline POU3FI & NM 002699 & $\begin{array}{l}\text { POU domain, class 3, transcription } \\
\text { factor I (SCIP/Oct-6) }\end{array}$ & $\begin{array}{l}\text { Serves as transcriptional } \\
\text { transactivator in the nucleus }\end{array}$ & 3 \\
\hline$M \times 2$ & $\underline{M 30818}$ & Myxovirus (influenza) resistance 2 & Possible antiviral potential & 3 \\
\hline LAPTM5 & NM 006762 & $\begin{array}{l}\text { Lysosomal-associated multispanning } \\
\text { membrane protein-5 }\end{array}$ & $\begin{array}{l}\text { Possible involvement in B cell } \\
\text { activation }\end{array}$ & 3 \\
\hline HBA2 & NM 000517 & Hemoglobin, alpha 2 & Oxygen transport & 3 \\
\hline $\mathrm{HBB}$ & NM 000518 & Hemoglobin, beta & Oxygen transport & 3 \\
\hline
\end{tabular}


Särkijärvi

Figure 2

a


b
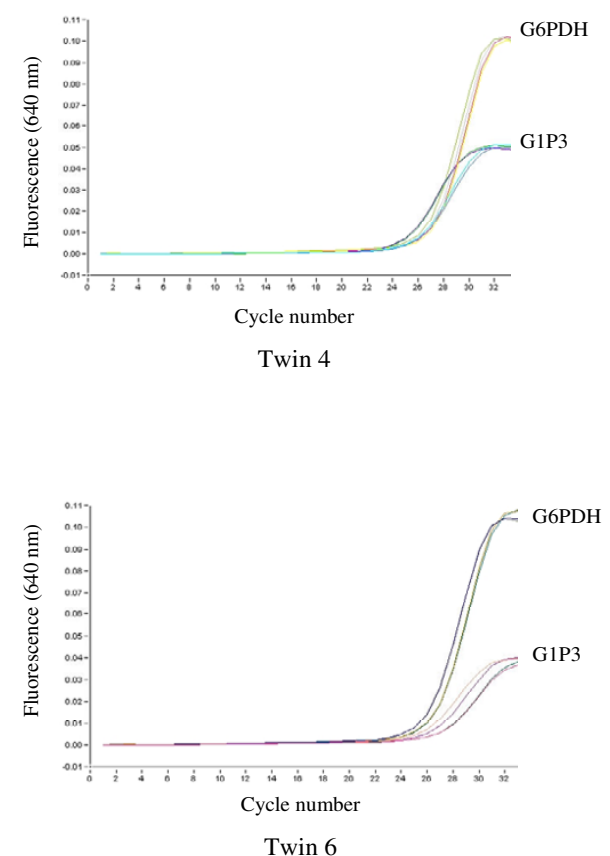

\begin{tabular}{llll}
\hline Twin & cDNA microarray result & QRT-PCR result & IFN- $\beta$ treatment \\
\hline Twin 3 & 2.0 & 2.8 & Yes \\
Twin 4 & 2.5 & 1.5 & No \\
Twin 5 & 8.2 & 6.8 & Yes \\
Twin 6 & 3.2 & 3.1 & Yes \\
Mean & 4.0 & 3.6 & \\
\hline
\end{tabular}

\section{Figure 2}

GIP3 gene analyzed by QRT-PCR. Glucose-6-phosphate dehydrogenase (G6PDH) was used as a reference gene in relative quantification. The expression of GIP3 was on average 3.6 times higher in MS twins compared to their healthy siblings, and the results concurred with those obtained from cDNA microarray. Panel a shows the real-time QRT-PCR amplifications duplicate in each twin pair $(3-6)$ and the table (panel b) shows the comparison between the CDNA microarray results and the QRT$P C R$ results. The $y$ axis indicates fluorescence intensity and $x$ axis PCR cycle numbers. GIP3 gene amplification begins earlier in MS patients than in their healthy siblings, indicating higher gene expression in MS twins. 
The MX2 gene was also up-regulated in twins with MS. Mx proteins are induced specifically by IFN- $\alpha$ and $-\beta[34,35]$ and have antiviral activities [36]. The antiviral potential or other functions of the MxB protein encoded by MX2 gene are not fully understood, while human MxA protein has a wide antiviral spectrum [37] and relatively high levels of its mRNA have been detected after treatment with IFN- $\beta$ [38]. Since up-regulated MX2 gene was observed in MS twins treated with IFN- $\beta$, its up-regulation may be explained by this treatment or alternatively by unknown virus infection.

The up-regulated LAPTM5 gene detected in twins with MS is conserved across evolution but it encodes protein which has no homology to any of the other lysosomal proteins [39]. ${ }^{37}$ LAPTM5 is also known as Clast6 and has been found to be highly expressed in progenitor and precursor B cells [40]. The protein may function during B cell activation or it could have a role in the antigen processing in lysosomes [40], which may be of relevance in MS.

Up-regulated HBA2 and HBB genes detected in MZ MS twins translate proteins that are part of a hemoglobin molecule. Heme units contain iron, which is involved in myelin production by oligodendrocytes and participates in the initiation of oxidative stress-induced injury in the CNS [41]. It is noteworthy that this process plays a role also in the pathogenesis of MS [41].

\section{Conclusion}

Taken together, in this study comparison of gene expression profiles in MZ MS twins to the corresponding profiles of their healthy siblings showed over two-fold up-regulation of six genes in almost half of twins with MS. This observation is of importance taking into account the restricted availability of $\mathrm{MZ}$ twins discordant for MS. However, given the sample size, clinical variation among subjects and limitations of the cross-sectional design, our results should be regarded as descriptive and hypothesis generating. To confirm the data $\mathrm{MZ}$ pairs discordant for MS need to be studied in other populations. Currently we are in a process of confirming our data with higher number of patients with MS.
Abbreviations
CCR5 = chemokine receptor 5
CNS = central nervous system
CTLA4 = cytotoxic T-lymphocyte-associated 4 gene
$\mathrm{DZ}=$ dizygotic
EDSS $=$ Expanded Disability Status Scale

ESR1 = estrogen receptor 1

G1P3 = Interferon-induced protein

HBA2 = hemoglobin alpha 2

HBB = hemoglobin beta

ICAM-1 = intercellular adhesion molecule-1

IL-1RA = interleukin-1 receptor antagonist

LAPTM5 = Lysosomal-associated multispanning membrane protein-5

$\mathrm{MBP}=$ myelin basic protein

MRI = magnetic resonance imaging

MS = multiple sclerosis

$\mathrm{MV}=$ measles virus

MX2 = Myxovirus (influenza) resistance 2

$\mathrm{MZ}=$ monozygotic

PAI-1 = plasminogen activator inhibitor 1

POU3F1 = POU domain, class 3 , transcription factor 1

QRT-PCR = quantitative reverse transcription polymerase chain reaction

\section{Competing interests}

The author(s) declare that they have no competing interests.

\section{Authors' contributions}

SS carried out the experimental work and helped drafting of the manuscript. HK carried out the neurological examination of the patients and participated in drafting of the manuscript. RP, MK and NA participated in the experimental work. TL, JK and MK helped to plan the study and to draft the manuscript. IE was the responsible investigator of the study and participated in planning of the study and drafting of the manuscript.

\section{Acknowledgements}

The authors thank Shaheenul Islam M.D. for performing statistical analyses with STATA software. Funding for this study was provided by the Academy of Finland (grant number 206382) and the Medical Research Fund of Tampere University Hospital. 


\section{References}

I. Sumelahti ML, Tienari PJ, Wikstrom J, Palo J, Hakama M: Increasing prevalence of multiple sclerosis in Finland. Acta Neurol Scand 2001, I03:153-158.

2. Ebers GC, Bulman DE, Sadovnick AD, Paty DW, Warren S, Hader W Murray TJ, Seland TP, Duquette P, Grey T: A population-based study of multiple sclerosis in twins. $N$ Engl J Med 1986 3 I5: 1638-1642.

3. Mumford CJ, Wood NW, Kellar-Wood H, Thorpe JW, Miller DH, Compston DA: The British Isles survey of multiple sclerosis in twins. Neurology 1994, 44: I I-I5.

4. Sadovnick AD, Armstrong H, Rice GP, Bulman D, Hashimoto L, Paty DW, Hashimoto SA, Warren S, Hader W, Murray T], Seland TP, Metz L, Bell R, Duquette P, Gray T, Nelson R, Weinshenkar B, Brunt D, Ebers GC: A population-based study of multiple sclerosis in twins: update. Ann Neurol 1993, 33:281-285.

5. Kinnunen E, Juntunen J, Ketonen L, Koskimies S, Konttinen YT, Salm $\mathrm{T}$, Koskenvuo M, Kaprio J: Genetic susceptibility to multiple sclerosis. A co-twin study of a nationwide series. Arch Neurol I988, 45: I 108-IIII.

6. Rasmussen HB, Kelly MA, Clausen J: Additive effect of the HLADRI 5 haplotype on susceptibility to multiple sclerosis. Mult Scler 2001, 7:91-93.

7. Bonetti A, Reunanen K, Finnila S, Koivisto K, Wikstrom J, Sumelahti ML, Pirttila T, Elovaara I, Reunanen M, Saarela J, Peltonen L, Rantamak T, Tienari PJ: A two-stage study on multiple sclerosis susceptibility and chromosome 2q33. Genes Immun 2004, 5: I42-I46.

8. Jalonen TO, Pulkkinen K, Ukkonen M, Saarela M, Elovaara I: Differential intracellular expression of CCR5 and chemokines in multiple sclerosis subtypes. I Neurol 2002, 249:576-583.

9. Luomala M, Elovaara I, Ukkonen M, Koivula T, Lehtimaki T: The combination of HLA-DRI and HLA-DR53 protects against MS. Neurology 200I, 56:383-385.

10. Luomala M, Elovaara I, Ukkonen M, Koivula T, Lehtimaki T: Plasminogen activator inhibitor I gene and risk of MS in women. Neurology 2000, 54:1862-1864.

II. Luomala M, Lehtimaki T, Elovaara I, Wang X, Ukkonen M, Mattila K, Laippala P, Koivula T, Hurme M: A study of interleukin-I cluster genes in susceptibility to and severity of multiple sclerosis. Neurol Sci 2001, I 85: 123-127.

12. Luomala M, Lehtimaki $T$, Huhtala $H$, Ukkonen $M$, Koivula $T$, Hurme $M$, Elovaara I: Promoter polymorphism of IL- I 0 and severity of multiple sclerosis. Acta Neurol Scand 2003, 1 08:396-400.

13. Mattila KM, Luomala M, Lehtimaki T, Laippala P, Koivula T, Elovaara I: Interaction between ESRI and HLA-DR2 may contribute to the development of $M S$ in women. Neurology 200I, 56: $1246-1247$.

14. Nejentsev S, Laaksonen M, Tienari PJ, Fernandez O, Cordell H, Ruutiainen J, Wikstrom J, Pastinen T, Kuokkanen S, Hillert J, llonen J: Intercellular adhesion molecule-I K469E polymorphism: study of association with multiple sclerosis. Hum Immunol 2003, 64:345-349.

I5. Pihlaja H, Rantamaki T, Wikstrom J, Sumelahti ML, Laaksonen M, Ilonen J, Ruutiainen J, Pirttila T, Elovaara I, Reunanen M, Kuokkanen S Peltonen L, Koivisto K, Tienari PJ: Linkage disequilibrium between the MBP tetranucleotide repeat and multiple sclerosis is restricted to a geographically defined subpopulation in Finland. Genes Immun 2003, 4:138-146.

16. Grekova MC, Robinson ED, Faerber MA, Katz P, McFarland HF, Richert JR: Deficient expression in multiple sclerosis of the inhibitory transcription factor $\mathrm{Sp} 3$ in mononuclear blood cells. Ann Neurol 1996, 40:108-12.

17. Poser CM, Paty DW, Scheinberg L, McDonald WI, Davis FA, Ebers GC, Johnson KP, Sibley WA, Silberberg DH, Tourtellotte WW: New diagnostic criteria for multiple sclerosis: guidelines for research protocols. Ann Neurol 1983, I 3:227-231.

18. Chen Y, Dougherty ER, Bittner ML: Ratio-Based Decisions and the Quantitative Analysis of cDNA Microarray Images. Journal of Biomedical Optics 1997, 2:364-374.

19. Claverie JM: Computational methods for the identification of differentialand coordinated gene expression. Hum Mol Genet 1999, 8:1821-1832.

20. Kaprio J, Koskenvuo M: Genetic and environmental factors in complex diseases: the older Finnish Twin Cohort. Twin Research 2002, 5:358-365.
21. Friedman RL, Manly SP, McMahon M, Kerr IM, Stark GR: Transcriptional and posttranscriptional regulation of interferoninduced gene expression in human cells. Cell I 984, 38:745-755.

22. Hibbert L, Foster GR: Human type I interferons differ greatly in their effects on the proliferation of primary B cells. J Interferon Cytokine Res 1999, 19:309-318.

23. Kelly JM, Porter AC, Chernajovsky Y, Gilbert CS, Stark GR, Kerr IM: Characterization of a human gene inducible by alpha- and beta-interferons and its expression in mouse cells. Embo J 1986, 5:1601-1606.

24. Clauss IM, Wathelet MG, Szpirer J, Content J, Islam MQ, Levan G, Szpirer C. Huez GA: Chromosomal localization of two human genes inducible by interferons, double-stranded RNA, and viruses. Cytogenet Cell Genet 1990, 53:166-168.

25. Wathelet MG, Clauss IM, Paillard FC, Huez GA: 2-Aminopurine selectively blocks the transcriptional activation of cellular genes by virus, double-stranded RNA and interferons in human cells. Eur J Biochem 1989, I 84:503-509.

26. Zhu H, Zhao H, Collins CD, Eckenrode SE, Run Q, Mclndoe RA, Crawford JM, Nelson DR, She JX, Liu C: Gene expression associated with interferon alfa antiviral activity in an HCV replicon cell line. Hepatology 2003, 37: I I80- I I88.

27. Chernajovsky $Y$, Reid TR: Regulation of the human interferoninducible 6-16 promoter in tumor necrosis factor-sensitive and resistant mouse cells: role of CAMP as a mediator of signal transduction. J Interferon Res 1990, 1 0:627-636.

28. Herberts CA, van Gaans-van den Brink J, van der Heeft E, van Wijk M, Hoekman J, Jaye A, Poelen MC, Boog CJ, Roholl PJ, Whittle H, de Jong $A P$, van Els $C C$ : Autoreactivity against induced or upregulated abundant self-peptides in HLA-A*020 I following measles virus infection. Hum Immunol 2003, 64:44-55.

29. Liebert UG, ter Meulen V: Synergistic interaction between measles virus infection and myelin basic protein peptide-specific $T$ cells in the induction of experimental allergic encephalomyelitis in Lewis rats. J Neuroimmunol 1993, 46:2 I7-223.

30. Link H, Sun JB, Wang Z, Xu Z, Love A, Fredrikson S, Olsson T: Virusreactive and autoreactive $T$ cells are accumulated in cerebrospinal fluid in multiple sclerosis. I Neuroimmunol 1992, 38:63-73.

31. Ohara Y: Multiple sclerosis and measles virus. Jpn J Infect Dis 1999, 52:198-200.

32. Sim FJ, Zhao C, Li WW, Lakatos A, Franklin RJ: Expression of the POU-domain transcription factors SCIP/Oct-6 and Brn-2 is associated with Schwann cell but not oligodendrocyte remyelination of the CNS. Mol Cell Neurosci 2002, 20:669-682.

33. Wegner M, Drolet DW, Rosenfeld MG: Regulation of JC virus by the POU-domain transcription factor Tst-I: implications for progressive multifocal leukoencephalopathy. Proc Natl Acad Sci USA 1993, 90:4743-4747.

34. Simon A, Fah J, Haller O, Staeheli P: Interferon-regulated Mx genes are not responsive to interleukin-I, tumor necrosis factor, and other cytokines. J Virol I99I, 65:968-971.

35. Staeheli P: Interferon-induced proteins and the antiviral state. Adv Virus Res 1990, 38: 147-200.

36. Haller O, Frese M, Kochs G: Mx proteins: mediators of innate resistance to RNA viruses. Rev Sci Tech 1998, 17:220-230.

37. Haller $O$, Kochs $G$ : Interferon-induced $\mathbf{m x}$ proteins: dynaminlike GTPases with antiviral activity. Traffic 2002, 3:710-717.

38. Bertolotto A, Gilli F, Sala A, Audano L, Castello A, Magliola U, Melis F, Giordana MT: Evaluation of bioavailability of three types of IFNbeta in multiple sclerosis patients by a new quantitativecompetitive-PCR method for MxA quantification. I Immunol Methods 200I, 256:14|-I52.

39. Adra CN, Zhu S, Ko J-L, Guillemot J-C, Cuervo AM, Kobayashi H, Horiuchi T, Lelias J-M, Rowley JD, Lim B: LAPTM5: A Novel Lysosomal-Associated Multispanning Membrane Protein Preferentially Expressed in Hematopoietic Cells. Genomics 1996 , 35:328-337.

40. Seimiya M, O-Wang J, Bahar R, Kawamura K, Wang $Y$, Saisho $H$, Tagawa M: Stage-specific expression of Clast6/E3/LAPTM5 during $B$ cell differentiation: elevated expression in human $B$ lymphomas. Int J Oncol 2003, 22:301-304.

41. Connor JR, Menzies SL: Relationship of iron to oligodendrocytes and myelination. Glia 1996, I 7:83-93. 


\section{Pre-publication history}

The pre-publication history for this paper can be accessed here:

http://www.biomedcentral.com/1471-2350/7/11/prepub

Publish with Bio Med Central and every scientist can read your work free of charge

"BioMed Central will be the most significant development for disseminating the results of biomedical research in our lifetime. " Sir Paul Nurse, Cancer Research UK

Your research papers will be:

- available free of charge to the entire biomedical community

- peer reviewed and published immediately upon acceptance

- cited in PubMed and archived on PubMed Central

- yours - you keep the copyright
BiolMedcentral 